\title{
Effects of season and testosterone treatment on gonadotrophin secretion and pituitary responsiveness to gonadotrophin-releasing hormone in castrated Romney and Poll Dorset rams
}

\author{
Z. Z. Xu, M. F. McDonald, S. N. McCutcheon and H. T. Blair \\ Department of Animal Science, Massey University, Palmerston North, New Zealand
}

\begin{abstract}
Summary. In castrated rams (Romney and Poll Dorset, $n=8$ for each breed), inhibition by testosterone treatment (administered via Silastic capsules) of luteinizing hormone (LH) pulse frequency, basal and mean $\mathrm{LH}$ concentrations, mean folliclestimulating hormone (FSH) concentration, and the peak and total $\mathrm{LH}$ responses to exogenous gonadotrophin-releasing hormone $(\mathrm{GnRH})$ were significantly $(P<0.01)$ greater during the nonbreeding than during the breeding season. Poll Dorset rams were less sensitive to testosterone treatment than Romney rams. In rams not receiving testosterone treatment, LH pulse frequency was significantly $(P<0.05)$ lower during the nonbreeding season than during the breeding season in the Romneys (15.8 \pm 0.9 versus $12.0 \pm 0.4$ pulses in $8 \mathrm{~h}$ ), but not in the Poll Dorsets $(13.6 \pm 1.2$ versus $12.8 \pm 0.8$ pulses in $8 \mathrm{~h}$ ). It is concluded that, in rams, season influences gonadotrophin secretion through a steroid-independent effect (directly on hypothalamic GnRH secretion) and a steroid-dependent effect (indirectly on the sensitivity of the hypothalamo-pituitary axis to the negative feedback of testosterone). The magnitude of these effects appears to be related to the seasonality of the breed.
\end{abstract}

Keywords: season; testosterone feedback; FSH; LH; breed effect; Romney; Poll Dorset; sheep

\section{Introduction}

It has been clearly demonstrated that, in rams and ewes, photoperiod influences reproductive activities through its effects on gonadotrophin secretion (Lincoln \& Short, 1980; Karsch et al., 1984). Studies in ewes show that photoperiod affects pituitary gonadotrophin secretion through both a direct effect on hypothalamic gonadotrophin-releasing hormone (GnRH) secretion (the steroid-independent effect) and an indirect effect on the sensitivity of the hypothalamo-pituitary axis to the negative feedback effect of oestradiol (the steroid-dependent effect, Karsch et al., 1984). Whereas studies in castrated rams have shown a pattern of seasonal changes in gonadotrophin secretion similar to those observed in intact rams (Pelletier \& Ortavant, 1975a; Lincoln \& Short, 1980; Sanford et al., 1984), there has been little detailed study of seasonal changes in hypothalamopituitary sensitivity to the negative feedback effects of testosterone in the ram (Pelletier \& Ortavant, 1975b; Schanbacher, 1980a). Clearly, further studies are needed to investigate the mechanisms by which photoperiod affects gonadotrophin secretion in rams.

It is well known that large breed differences exist in length of the breeding season (Hafez, 1952). In the ram these are manifested in differences in the timing and magnitude of seasonal variation in testis size, semen production and libido (Haynes \& Schanbacher, 1983). Studies in ewes show that breed differences in seasonality may be related to the sensitivity of the hypothalamo-pituitary axis to both the direct and indirect effects of photoperiod (Martin et al., 1983; Webster \& Haresign, 
1983; Karsch et al., 1984; Thomas et al., 1988). However, there has been no comparative study conducted in the ram of breed differences in sensitivity to the steroid-independent and steroiddependent effects of photoperiod. The present study was therefore conducted to investigate the effect of season on gonadotrophin secretion in castrated Poll Dorset and Romney rams, half of which had been treated with testosterone administered via Silastic capsules to: (i) confirm the existence of both steroid-dependent and steroid-independent effects of season on gonadotrophin secretion in the ram and (ii) compare differences between breeds of short (Romney) versus long (Poll Dorset) breeding season in their sensitivity to seasonal effects with respect to gonadotrophin secretion.

\section{Materials and Methods}

\section{Animals and experimental procedure}

The experiment was a balanced $2 \times 2$ factorial design involving two breeds (Romney versus Poll Dorset) and two testosterone treatments (control versus testosterone-treated) repeated during two seasons (breeding and nonbreeding). Sixteen castrated mature rams (eight Romney and eight Poll Dorset) were used in this trial. These rams were castrated under general anaesthesia in late August 1989. Immediately after castration, half of the animals in each breed were implanted with eight testosterone-filled Silastic capsules (testosterone-treated group) and the remaining animals (control group) each received eight empty capsules. Details of the capsules are provided below. Immediately before implantation, the capsules were sterilized by rinsing in $70 \%$ ethanol. Capsules were implanted with a trocar on one side of the body, over the ribs just behind the shoulder, under local anaesthesia. On two occasions (20 April and 7 November, 1990) corresponding to the breeding and nonbreeding seasons respectively at this latitude (40.1 $\left.{ }^{\circ} \mathrm{S}\right)$, the animals were subjected to intensive blood sampling and GnRH challenge studies. Eight weeks before each planned date of blood sampling, the old testosterone capsules were removed and new ones implanted on the opposite side of the body. The empty capsules in control animals were also taken out and reimplanted on the opposite side of the body. This procedure was undertaken to ensure that the testosterone concentrations maintained by the capsules were the same for both seasons.

Ten days before each planned sampling date, the animals were transferred indoors from pasture and housed in metabolism crates to allow them to adjust to the indoor conditions and human handling. The room in which the animals were housed had large windows so that rams were exposed only to natural light (except on the night of blood sampling when artificial light was used until completion of the sampling). While indoors, the rams received a maintenance diet of chaffed lucerne hay supplemented with minerals to counteract possible copper toxicity (Rattray, 1986). Fresh water was available ad libitum. The rams were returned to pasture 3 days after completion of each blood sampling period. While outdoors, they were managed as a single group separate from the ewe flock and grazed on mixed ryegrass/clover pastures.

Jugular vein cannulae were inserted as described by Carter et al. (1989) one day before the date of blood sampling. At each sampling period, $6 \mathrm{ml}$ of blood was collected at 12-min intervals for $8 \mathrm{~h}$ commencing at $08: 30 \mathrm{~h}$. After the last sample was taken $(16: 30 \mathrm{~h}$ ), each animal received an intravenous injection of synthetic GnRH (NIDDK, NIH) at a dose of $50 \mathrm{ng} \mathrm{kg}^{-1}$ liveweight. The $\mathrm{GnRH}$ was dissolved at a concentration of $1 \mu \mathrm{g} \mathrm{ml} \mathrm{l}^{-1}$ in saline $1 \mathrm{~h}$ before injection and administered via the cannulae followed by $4 \mathrm{ml}$ of heparinized saline to flush the cannulae. Further blood samples were collected at 10,20,30,45,60,80,100,120,150 and $180 \mathrm{~min}$ after GnRH injection. All blood samples were collected into heparinized tubes and immediately placed on ice. Within 25 min of collection, they were centrifuged at $3000 \mathrm{~g}$ and $4^{\circ} \mathrm{C}$ for $20 \mathrm{~min}$. The plasma was harvested and stored in duplicate vials at $-20^{\circ} \mathrm{C}$ until hormone analyses were conducted.

\section{Testosterone capsules}

The testosterone capsules were prepared according to Schanbacher (1980b). Medical grade Silastic tubing ( $3.35 \mathrm{~mm}$ inner diameter, $4.65 \mathrm{~mm}$ outer diameter; Dow Corning, Midland, MI, USA) was cut into 15 -cm lengths and sealed at one end with Silastic Adhesive Type A (Dow Corning, Midland, MI, USA). The tubes were packed with crystalline testosterone (Cat. No. T-1500: Sigma Chemical Company, St Louis, MO, USA) $24 \mathrm{~h}$ later and the open end sealed with adhesive. Empty capsules were made by sealing both ends of the tubes with adhesive. The capsules were left in the air to dry for a week and then stored in a desiccator until needed.

\section{Hormone assays}

Luteinizing hormone. Plasma LH was measured using a homologous double-antibody radioimmunoassay kit provided by the National Hormone and Pituitary Program (NHPP) and the National Institute of Diabetic and Digestive and Kidney Diseases (NIDDK), Maryland, USA. NIADK-oLH-25 (biopotency $=2 \cdot 3 \times$ NIH-LH-S1) was 
used as the reference standard. The assay sensitivity (calculated as the $95 \%$ confidence limit of buffer control tubes) was $0 \cdot 10 \pm 0.01 \mathrm{ng} \mathrm{ml}^{-1}$. The intra-assay coefficients of variation (CV) were $7 \cdot 1,3 \cdot 5$ and $5 \cdot 1 \%$, and the inter-assay CV $8.6,3.5$ and $8.5 \%$, at mean LH concentrations of $1.0,2.5$ and $9.9 \mathrm{ng} \mathrm{ml}^{-1}$, respectively. Reference pools used for calculation of $\mathrm{CV}$ were prepared by spiking ram plasma with NIADK-oLH-25.

Follicle-stimulating hormone. Plasma FSH was measured using a homologous double-antibody radioimmunoassay kit provided by NHPP and NIDDK. The reference standard was NIAMDD-oFSH-RP-1 and assay sensitivity was $0.10 \pm 0.03 \mathrm{ng} \mathrm{ml}^{-1}$. The intra-assay CV were 5.3 and $4.8 \%$, and inter-assay CV 6.5 and $5.0 \%$, at mean FSH concentrations of $2 \cdot 2$ and $4.4 \mathrm{ng} \mathrm{ml}^{-1}$ respectively. Reference pools used for calculation of $\mathrm{CV}$ were prepared by spiking ram plasma with NIAMDD-oFSH-RP-I.

Testosterone. Since it has been shown that Silastic capsules similar to those used in the present study maintain constant plasma testosterone concentrations over a 24-h sampling period (D'Occhio et al., 1982), plasma samples taken from each ram during each 8-h basal sampling period were pooled. They were assayed for testosterone by radioimmunoassay based on the method described by Smith \& Hafs (1973), as modified and validated by Wilson \& Lapwood (1978). All samples from the study were analysed in one assay run. The assay sensitivity was $0.12 \mathrm{ng} \mathrm{ml}^{-1}$ and the intra-assay CV was $14.5 \%$ at a testosterone concentration of $1.6 \mathrm{ng} \mathrm{ml}^{-1}$. Plasma pools from intact rams of the same breeds that had been sampled during the breeding season ( 15 March) and nonbreeding season ( 9 November) in another study (Z. Z. Xu, M. F. McDonald, S. N. McCutcheon \& H. T. Blair, unpublished data) were also assayed for testosterone, to determine whether the testosterone concentrations maintained by the capsules were in the normal physiological range for rams of these breeds.

\section{Data and statistical analyses}

Data relating to plasma LH in serial samples from individual rams at each season were processed by the computer program 'DETECT' to identify the presence of secretion pulses (Guardabasso et al., 1988). LH pulse frequency was expressed as the total number of pulses occurring during the 8-h sampling period and pulse amplitude was determined by the highest LH concentration associated with an individual puise minus the concentration at the onset of the pulse. Basal LH levels were obtained by averaging the concentrations of samples between adjacent pulses. Mean LH levels were calculated by averaging values for all the 40 samples taken from each animal during the 8-h period. The LH response to $\mathrm{GnRH}$ challenge was characterized by the peak response (the highest LH level after GnRH injection minus the basal level) and the total response (measured by the area under the response curve above the basal level as calculated by triangulation).

The data were subjected to analysis of variance for repeated measures with season being the repeated factor (SAS Institute Inc., 1988). Since there was a significant breed difference in plasma testosterone concentrations maintained by the implants (see Results), breed effects on other parameters were adjusted (within treatment) to a common mean testosterone concentration by covariance analysis to remove possible confounding of breed differences in plasma testosterone with the real breed effect. Comparisons of multiple means were performed using Duncan's multiple-range test.

\section{Results}

\section{Plasma testosterone concentration and liveweight}

The testosterone capsules maintained plasma testosterone concentrations in castrated rams that were slightly higher than (Romney), or similar to (Poll Dorset), those of intact rams during the nonbreeding season (Table 1). The testosterone capsules maintained similar plasma testosterone concentrations during both seasons, but Romney rams had significantly $(P<0 \cdot 01)$ higher testosterone concentrations than Poll Dorset rams. The Romney rams were also significantly $(P<0.01)$ lighter than the Poll Dorset rams. Adjustment to a common liveweight eliminated the significant breed effect on plasma testosterone concentrations. In rams implanted with empty capsules, plasma testosterone concentrations were low and close to the assay sensitivity $\left(0 \cdot 12 \mathrm{ng} \mathrm{ml}^{-1}\right)$.

\section{Basal and mean LH}

There were significant seasonal differences in the effects of testosterone treatment on the basal and mean LH concentrations ( $P<0.01$ for season $\times$ treatment interaction) (Table 2). During the breeding season, testosterone treatment had no significant effect on the basal or mean LH concentrations in either breed. However, during the nonbreeding season, testosterone treatment significantly $(P<0.01)$ inhibited the basal and mean LH concentrations in both breeds. 
Table 1. Plasma testosterone concentration and liveweight in control and testosterone-treated Romney and Poll Dorset castrated rams during the breeding and nonbreeding seasons with data for intact rams

\begin{tabular}{llcc}
\hline Breed & Season & $\begin{array}{c}\text { Testosterone } \\
\left(\mathrm{ng} \mathrm{ml}^{-1}\right)\end{array}$ & $\begin{array}{c}\text { Liveweight } \\
(\mathrm{kg})\end{array}$ \\
\hline Control, $n=4$ & Breeding & $0 \cdot 12 \pm 0 \cdot 05^{\mathrm{a}}$ & $61 \cdot 5 \pm 3 \cdot 4^{\mathrm{a}}$ \\
$\quad$ Romney & Nonbreeding & $0 \cdot 15 \pm 0 \cdot 04^{\mathrm{a}}$ & $63 \cdot 3 \pm 3 \cdot 7^{\mathrm{a}}$ \\
Romney & Breeding & $0 \cdot 11 \pm 0 \cdot 03^{\mathrm{a}}$ & $71 \cdot 4 \pm 1 \cdot 9^{\mathrm{b}}$ \\
Poll Dorset & Nonbreeding & $0 \cdot 14 \pm 0 \cdot 03^{\mathrm{a}}$ & $72 \cdot 0 \pm 1 \cdot 0^{\mathrm{b}}$ \\
$\quad$ Poll Dorset & & & \\
Testosterone- & & & \\
treated, $n=4$ & & $2 \cdot 01 \pm 0 \cdot 33^{\mathrm{b}}$ & $62 \cdot 4 \pm 1 \cdot 0^{\mathrm{a}}$ \\
Romney & Breeding & $1 \cdot 91 \pm 0 \cdot 36^{\mathrm{b}}$ & $64 \cdot 0 \pm 2 \cdot 1^{\mathrm{a}}$ \\
Romney & Nonbreeding & $1 \cdot 38 \pm 0 \cdot 15^{\mathrm{c}}$ & $73 \cdot 9 \pm 2 \cdot 1^{\mathrm{b}}$ \\
Poll Dorset & Breeding & $1 \cdot 30 \pm 0 \cdot 13^{\mathrm{c}}$ & $73 \cdot 5 \pm 2 \cdot 8^{\mathrm{b}}$ \\
Poll Dorset & Nonbreeding & & \\
Intact, $n=6$ & & & \\
Romney & Breeding & $6 \cdot 15 \pm 0 \cdot 73^{\mathrm{d}}$ & \\
Romney & Nonbreeding & $1 \cdot 01 \pm 0 \cdot 28^{\mathrm{c}}$ & \\
Poll Dorset & Breeding & $3 \cdot 10 \pm 1 \cdot 06^{\mathrm{c}}$ & \\
Poll Dorset & Nonbreeding & $1 \cdot 28 \pm 0 \cdot 45^{\mathrm{c}}$ & \\
\hline
\end{tabular}

Values presented are means \pm SEM.

a.b.c.d Means within each column carrying the same superscript do not differ significantly $(P>0 \cdot 05)$.

Table 2. Basal and mean luteinizing hormone (LH) concentrations, LH pulse frequency, LH pulse amplitude and mean follicle-stimulating hormone (FSH) concentration in control and testosteronetreated Romney and Poll Dorset castrated rams during the breeding and nonbreeding seasons

\begin{tabular}{|c|c|c|c|c|c|c|}
\hline Season & Treatment & $\begin{array}{c}\text { Basal LH } \\
\text { concentration } \\
\left(\mathrm{ng} \mathrm{ml}^{-1}\right)\end{array}$ & $\begin{array}{c}\text { Mean LH } \\
\text { concentration } \\
\left(\mathrm{ng} \mathrm{ml}^{-1}\right)\end{array}$ & $\begin{array}{c}\text { LH pulse } \\
\text { frequency } \\
\text { (pulses in } 8 \mathrm{~h} \text { ) }\end{array}$ & $\begin{array}{l}\text { LH pulse } \\
\text { amplitude } \\
\left(\mathrm{ng} \mathrm{ml}^{-1}\right)\end{array}$ & $\begin{array}{l}\text { Mean FSH } \\
\text { concentration } \\
\left(\mathrm{ng} \mathrm{ml}^{-1}\right)\end{array}$ \\
\hline \multicolumn{7}{|l|}{ Romney $(n=4)$} \\
\hline Breeding & Control & $2 \cdot 12 \pm 0.56^{\mathrm{ac}}$ & $2.45 \pm 0.6 \mathrm{l}^{\mathrm{ac}}$ & $15.8 \pm 0.9^{b}$ & $0.73 \pm 0 \cdot 11^{\mathrm{a}}$ & $13.75 \pm 1.17^{\mathrm{ab}}$ \\
\hline Breedir & sterone & $30=$ & 1.59 & $7 \cdot 6 \pm 2 \cdot 1^{\mathrm{a}}$ & $0.76 \pm 0$ & $13 \cdot 13=$ \\
\hline Nonbreeding & Control & $2.03 \pm 0.45^{\mathrm{ac}}$ & $2 \cdot 56 \pm$ & $12 \cdot 0 \pm 0 \cdot 4^{\mathrm{c}}$ & $1 \cdot 20 \pm 0.18^{\mathrm{ab}}$ & $11.87 \pm 0.70^{\mathrm{ab}}$ \\
\hline Nonbreeding & Testosterone & $0.25 \pm 0.01^{b}$ & $0.25 \pm 0.0 \mathrm{I}^{\mathrm{b}}$ & & & $0.47 \pm 0.04^{\mathrm{d}}$ \\
\hline \multicolumn{7}{|c|}{ Poll Dorset $(n=4)$} \\
\hline Breedi & Cont & $2 \cdot 72 \pm$ & $3 \cdot 38 \pm 0 \cdot 3 l^{c}$ & $13 \cdot 6 \pm 1 \cdot 2^{b c}$ & $1 \cdot 37 \pm 0 \cdot 12^{\mathrm{ab}}$ & $21 \cdot 28 \pm 3 \cdot 26^{a c}$ \\
\hline Breeding & Testosterone & $2.75 \pm 0.25^{\mathrm{c}}$ & $3.50 \pm 0.4 \mathrm{I}^{\mathrm{c}}$ & $12.4 \pm 0.9^{b c}$ & $I .91 \pm 0.56^{\mathrm{b}}$ & $23 \cdot 40 \pm 2 \cdot 12^{\mathrm{c}}$ \\
\hline Nonbreeding & Control & $2.87 \pm 0.47^{\mathrm{c}}$ & $3.44 \pm 0.56^{\mathrm{c}}$ & $12 \cdot 8 \pm 0 \cdot 8^{\mathrm{bc}}$ & $1 \cdot 25 \pm 0 \cdot 30^{\mathrm{ab}}$ & $20 \cdot 83 \pm 2 \cdot 86^{\mathrm{ac}}$ \\
\hline Nonbreeding & Testosterone & $0.79 \pm 0.38^{\mathrm{b}}$ & $1.40 \pm 0.68^{\mathrm{ab}}$ & $2 \cdot 1 \pm 1 \cdot 3^{d}$ & $4.43 \pm 0.66^{\mathrm{c}}$ & $9 \cdot 45 \pm 5 \cdot 88^{b}$ \\
\hline
\end{tabular}

Values presented are mean \pm SEM.

a.b,c,d Means within each column carrying the same superscript do not differ significantly $(P>0 \cdot 05)$.

\section{LH pulse frequency}

The effect of testosterone treatment on $\mathrm{LH}$ pulse frequency was significantly influenced by season and breed $(P<0.01$ for season $\times$ treatment interaction, $P<0.05$ for breed $\times$ treatment interaction) (Table 2$)$. In Romney rams, testosterone treatment significantly $(P<0.01)$ suppressed LH pulse frequency during both seasons, but the suppression was greater during the nonbreeding season (from $12 \cdot 0$ to 0 pulses in $8 \mathrm{~h}$ ) than during the breeding season (from $15 \cdot 8$ to $7 \cdot 6$ pulses in $8 \mathrm{~h}$ ). 
In Poll Dorset rams, testosterone treatment had no significant effect on LH pulse frequency during the breeding season (13.6 versus 12.4 pulses in $8 \mathrm{~h}$ ). However, during the nonbreeding season, $\mathrm{LH}$ pulse frequency was significantly $(P<0 \cdot 01)$ reduced by testosterone treatment (from 12.8 to $2 \cdot 1$ pulses in $8 \mathrm{~h}$ ). The breeds also differed in their sensitivity to the direct effect of season. The reduction in LH pulse frequency from the breeding to the nonbreeding season in control rams (bearing empty capsules) was significant for the Romneys $(15.8$ versus 12.0 pulses in $8 \mathrm{~h}, P<0.05)$, but nonsignificant for the Poll Dorsets (13.6 versus 12.8 pulses in $8 \mathrm{~h}, P>0 \cdot 10$ ).

\section{LH pulse amplitude}

The effect of testosterone treatment on LH pulse amplitude (pooled across both breeds) differed significantly between seasons $(P<0.01$ for season $\times$ treatment interaction; Table 2$)$. Testosterone treatment had no significant effect on LH pulse amplitude during the breeding season, but it significantly $(P<0.01)$ increased LH pulse amplitude during the nonbreeding season.

\section{Follicle-stimulating hormone}

The effects of testosterone treatment on FSH concentrations differed significantly between the two seasons $(P<0.01$ for season $\times$ treatment interaction) (Table 2). During the breeding season, testosterone treatment had no significant effect on FSH concentrations, whereas it significantly $(P<0.01)$ reduced FSH concentrations during the nonbreeding season in both breeds. There were significant $(P<0.05)$ breed effects independent of season and treatment on FSH concentrations, which were higher in Poll Dorset rams than in Romney rams (18.7 versus $9.6 \mathrm{ng} \mathrm{ml}^{-1}$, least squares means).

\section{LH response to GnRH challenge}

The effects of testosterone treatment on both peak and total $\mathrm{LH}$ responses to $\mathrm{GnRH}$ challenge differed significantly between seasons $(P<0.01$ for season $\times$ treatment interaction) (Table 3$)$. During the breeding season, testosterone treatment had no significant effects on either peak or total LH responses to GnRH, whereas during the nonbreeding season it significantly $(P<0.01)$ reduced both peak and total responses. Poll Dorset rams had a significantly $(P<0.05)$ greater peak response to GnRH challenge than Romney rams. No other effects on either the peak or total responses to GnRH were significant.

\section{Discussion}

The present study investigated the effects of testosterone treatment on gonadotrophin secretion during both the breeding season and the nonbreeding season in castrated rams of the Romney and Poll Dorset breeds, the ewes of these breeds differ greatly in their seasonality (Hafez, 1952; Kelly et al., 1976; Knight et al., 1989). Recently castrated rams were used because there is evidence that rams castrated for long periods may lose their responsiveness to testosterone (Thieulant \& Pelletier, 1979). The first blood sampling took place about 7 months after castration, a period that should have been sufficient for gonadotrophin secretion to reach equilibrium after castration (Caraty, 1983; Montgomery et al., 1985). Differences between the two sampling periods would therefore reflect a true seasonal effect. The testosterone treatment used in the present study was effective in maintaining plasma testosterone concentrations at the lower end of the normal physiological range observed in intact rams of the same breeds. For the purposes of the present study, it was desirable to have plasma testosterone concentrations at the lower end of the normal physiological range to avoid masking the breed and seasonal differences by over-inhibition. 
Table 3. Peak and total luteinizing hormone $(\mathrm{LH})$ response to gonadotrophinreleasing hormone challenge in control and testosterone-treated Romney and Poll Dorset castrated rams during the breeding and nonbreeding seasons

\begin{tabular}{|c|c|c|c|}
\hline Season & Treatment & $\begin{array}{l}\text { Peak response } \\
\quad\left(\mathrm{ng} \mathrm{ml^{-1 }}\right)\end{array}$ & $\begin{array}{l}\text { Total response } \\
\quad\left(\mathrm{ng} \mathrm{ml}^{-1}\right)\end{array}$ \\
\hline \multicolumn{4}{|l|}{ Romney, $n=4$} \\
\hline Breeding & Control & $25.77 \pm 6.60^{\text {ac }}$ & $1621 \cdot 0 \pm 426 \cdot 5^{\mathrm{ab}}$ \\
\hline Breeding & Testosterone & $19.05 \pm 5.99^{\mathrm{ab}}$ & $1424.6 \pm 385.9^{\mathrm{ab}}$ \\
\hline Nonbreeding & Control & $21.54 \pm 4.82^{\mathrm{ab}}$ & $1277 \cdot 7 \pm 321 \cdot 0^{\mathrm{ab}}$ \\
\hline Nonbreeding & Testosterone & $1.88 \pm 0.41^{\mathrm{b}}$ & $157.1 \pm 45 \cdot 9^{c}$ \\
\hline \multicolumn{4}{|c|}{ Poll Dorset, $n=4$} \\
\hline Breeding & Control & $45.54 \pm 10 \cdot 80^{\mathrm{c}}$ & $2139 \cdot 7 \pm 399 \cdot 6^{\mathrm{a}}$ \\
\hline Breeding & Testosterone & $35 \cdot 86 \pm 4 \cdot 11^{\mathrm{ac}}$ & $1927 \cdot 3 \pm 222.8^{\mathrm{ab}}$ \\
\hline Nonbreeding & Control & $43.54 \pm 8.64^{\mathrm{c}}$ & $2160 \cdot 8 \pm 317 \cdot 7^{\mathrm{a}}$ \\
\hline Nonbreeding & Testosterone & $16 \cdot 76 \pm 8 \cdot 32^{\mathrm{ab}}$ & $994.3 \pm 464.9^{\mathrm{bc}}$ \\
\hline
\end{tabular}

The first important finding from the present study is that the effects of testosterone treatment on gonadotrophin secretion and pituitary responses to GnRH challenge were markedly affected by season. During the nonbreeding season, testosterone treatment significantly suppressed LH pulse frequency, mean and basal LH concentrations, FSH concentrations, and peak and total LH response to $\mathrm{GnRH}$ challenge. However, during the breeding season, most of the inhibitory effects of testosterone were lost and only the inhibition of LH pulse frequency in Romney rams remained. Even with LH pulse frequency, the reduction was smaller during the breeding season than during the nonbreeding season (Table 2). The greater inhibitory effects of testosterone on gonadotrophin secretion during the nonbreeding season compared with the breeding season confirm and extend the earlier observation by Pelletier \& Ortavant (1975b) that a single injection of testosterone propionate exerted a greater suppression of $\mathrm{LH}$ release in animals exposed to a 16 -h photoperiod than in animals exposed to an 8-h photoperiod. Thus, in the ram, one mechanism by which season affects gonadotrophin secretion is via its effect on the sensitivity of the hypothalamo-pituitary axis to the negative feedback effects of gonadal steroids, a feature that has been extensively investigated in ewes (Karsch et al., 1984) and male hamsters (Turek \& Ellis, 1981). Because of this seasonal variation in sensitivity of the hypothalamo pituitary axis to the negative feedback of testosterone, intact rams can maintain greater gonadotrophin secretion during the breeding season in the face of an increased negative feedback from the testis.

There are also breed differences in sensitivity to testosterone treatment. The LH pulse frequency of Romney rams was inhibited to a greater extent by testosterone treatment than was that of Poll Dorset rams. Testosterone significantly inhibited LH pulse frequency only during the nonbreeding season in Poll Dorset rams, whereas it significantly inhibited LH pulse frequency during both seasons in Romney rams. Thus the more seasonal Romney rams appeared to be more sensitive to testosterone inhibition than the less seasonal Poll Dorset rams. Similar differences in the sensitivity of the hypothalamo-pituitary axis to the negative feedback effect of oestradiol between ewes of breeds of long versus short breeding season have also been reported (Thomas et al., 1988). These results suggest that one way by which some breeds achieve a longer breeding season is by becoming less sensitive to the negative feedback effects of steroids, especially during long days. Some caution is, however, needed when interpreting the breed differences in sensitivity to testosterone treatment observed in the present study because of the breed differences in plasma testosterone concentrations maintained by the capsules. An attempt was made to remove this confounding effect by covariance analysis, but it is not known whether this procedure completely removed the effect of 
breed differences in plasma testosterone concentrations from the physiological, rather than the statistical, point of view. Further studies are required to confirm this.

Another finding from the present study was the observed breed difference in the seasonal variation in LH pulse frequency in rams not treated with testosterone. LH pulse frequency was significantly lower during the nonbreeding season than during the breeding season in Romney, but not in Poll Dorset, rams. This suggests that there is a direct, steroid-independent effect of season on hypothalamic GnRH secretion in the more seasonal Romney rams but not in the less seasonal Poll Dorset rams. This agrees with findings from studies comparing ovariectomized Suffolk and Merino ewes (Thomas et al., 1988). A direct effect of season on LH pulse frequency in castrated rams has also been observed by Sanford et al. (1984). In general, these studies suggest that there is, in both rams and ewes, a steroid-independent effect of season which directly influences hypothalamic GnRH secretion. However, the magnitude of this direct effect of season appears to be related to the seasonality of the breed concerned. This could be another way by which breed differences in length of the breeding season are achieved.

In conclusion, the present study showed that, in rams, season influences gonadotrophin secretion through both a steroid-dependent mechanism (indirectly affecting the sensitivity of the hypothalamo-pituitary axis to the negative feedback effect of testosterone) and a steroidindependent mechanism (directly affecting GnRH secretion from the hypothalamus). The sensitivity of the hypothalamo-pituitary axis to these seasonal effects varies among breeds differing in seasonality and may be the means by which breed differences in seasonality are achieved.

The authors thank M. F. Scott, Y. H. Cottam, F. S. Jackson, D. L. Burnham and C. M. C. Jenkinson for technical assistance; L. Watts and W. B. Parlane for care of the animals and provision of facilities; and all those who helped with blood sampling. The materials used in the FSH and LH assays and the GnRH study were kindly donated by the National Hormone and Pituitary Program, and the National Institute of Diabetic and Digestive and Kidney Diseases, Bethesda, MD, USA. The financial support of the C. Alma Baker Trust is gratefully acknowledged.

\section{References}

Caraty, A. (1983) Ram hypothalamic pituitary-gonadalinteractions. Effects of castration and cryptorchidism. Acta Endocrinologica 102, 292-298.

Carter, M.L., McCutcheon, S.N. \& Purchas, R.W. (1989) Plasma metabolite and hormone concentrations as predictors of genetic merit for lean meat production in sheep: effects of metabolic challenges and fasting. New' Zealand Journal of Agricultural Research 32, 343-353.

D'Occhio, M.J., Schanbacher, B.D. \& Kinder, J.E. (1982) Relationship between serum testosterone concentration and patterns of luteinizing hormone secretion in male sheep. Endocrinology 110, 1547-1554.

Guardabasso, V., Oerter, K.E., Iademarcl, M.F., Veldhuis, J.D. \& Rodbard, D. (1988) DETECT. A Program for Detection and Characterization of Peaks and Estimation of Instantaneous Secretory Rate, ISR, in Studies of Pulsatile Hormone Secretion. Version 5.0. Laboratory of Theoretical and Physical Biology, National Institute of Child Health and Human Development, NIH, Bethesda, MD, USA.

Hafez, E.S.E. (1952) Studies on the breeding season and reproduction of the ewe. Journal of Agricultural Science Cambridge 42, 189-265.

Haynes, N.B. \& Schanbacher, B.D. (1983) The control of reproductive activity in the ram. In Sheep Production, pp. 431-451. Ed. W. Haresign. Butterworths, London.
Karsch, F.J., Bittman, E.L., Foster, D.L., Goodman, R.L., Legan, S.J. \& Robinson, J.E. (1984) Neuroendocrine basis of seasonal reproduction. Recent Progress in Hormone Research 40, 185-232.

Kelly, R.W., Allison, A.J. \& Shackell, G.H. (1976) Seasonal variation in oestrous and ovarian activity of five breeds of ewes in Otago. New Zealand Journal of Experimental Agriculture 4, 209-214.

Knight, T.W., Kannegieter, S.G. \& Hamilton, G.J. (1989) Breeding season of Romney and Poll Dorset ewes at different locations and the reproductive penalties of a June joining. Proceedings of the New Zealand Society of Animal Production 49, 265-270.

Lincoln, G.A. \& Short, R.V. (1980) Seasonal breeding: nature's contraceptive. Recent Progress in Hormone Research 36, 1-52.

Martin, G.B., Scaramuzxi, R.J. \& Henstridge, J.D. (1983) Effects of oestradiol, progesterone and androstenedione on the pulsatile secretion of luteinizing hormone in ovariectomized ewes during spring and autumn. Journal of Endocrinology 96, 181-193.

Montgomery, G.W., Martin, G.B. \& Pelletier, J. (1985) Changes in pulsatile LH secretion after ovariectomy in Ile-de-France ewes in two seasons. Journal of Reproduction and Fertility 73, 173-183.

Pelletier, J. \& Ortavant, R. (1975a) Photoperiodic control of $\mathrm{LH}$ release in the ram. I. Influence of increasing and 
decreasing light photoperiods. Acta Endocrinologica $78,435-441$.

Pelletier, J. \& Ortavant, R. (1975b) Photoperiodic control of $\mathrm{LH}$ release in the ram. II. Light-androgens interaction. Acta Endocrinologica 78, 442-450.

Rattray, P.V. (1986) Feed requirement for maintenance, gain and production. In Sheep Production, Vol. 2. Feeding, Growth, and Health, pp. 75-109. Eds S. N. McCutcheon, M. F. McDonald \& G. A. Wickham. New Zealand Institute of Agricultural Science.

Sanford, L.M., Howland, B.E. \& Palmer, W.M. (1984) Seasonal changes in the secretion of gonadotropic hormones and in the endocrine response of the pituitary of male sheep in the absence of gonadal influence. Canadian Journal of Physiology and Pharmacology 62, 834-839.

SAS Institute, Inc. (1988) SAS/STAT User's Guide, Release 6.03 Edition. SAS Institute Inc., Cary, NC, USA.

Schanbacher, B.D. (1980a) The feedback control of gonadotrophin secretion by testicular steroids. Proceedings of the Ninth International Congress of Animal Reproduction and Artificial Insemination 2, 177-184.

Schanbacher, B.D. (1980b) Testosterone regulation of luteinizing hormone and follicle stimulating hormone secretion in young male lambs. Journal of Animal Science 51, 679-684.

Smith, O.W. \& Hafs, H.S. (1973) Competitive protein binding and radioimmunoassay for testosterone in bulls and rabbits; blood serum testosterone after injection of LH or prolactin in rabbits. Proceedings of Society for Experimental Biology and Medicine 142, 804-810.

Thieulant, M.L. \& Pelletier, J. (1979) Evidence for androgen and estrogen receptors in castrated ram pituitary cytosol: influence of time after castration. Journal of Steroid Biochemistry 10, 677-687.

Thomas, G.B., Pearce, D.T. Oldham, C.M., Martin, G.B. \& Lindsay, D.R. (1988) Effects of breed, ovarian steroids and season on the pulsatile secretion of LH in ovariectomized ewes. Journal of Reproduction and Fertility 84, 313-324.

Turek, F.W. \& Ellis, G.B. (1981) Steroid-dependent and steroid-independent aspects of the photoperiodic control of seasonal reproductive cycles in male hamsters. In Biological Clocks in Seasonal Reproductive Cycles, pp. 251-260. Eds B. K. \& D. E. Follett. Wright, Bristol.

Webster, G.A. \& Haresign, W. (1983) Seasonal changes in $\mathbf{L H}$ and prolactin concentrations in ewes of two breeds. Journal of Reproduction and Fertility 67, $465-471$.

Wilson, P.R. \& Lapwood, K.R. (1978) Studies of hormone secretion in Romney rams: luteinizing hormone, testosterone and prolactin plasma profiles, $\mathrm{LH} /$ testosterone interrelationships and the influence of seasons. Theriogenology 9, 279-294.

Received 19 February 1991 